\title{
THE ANTI HYPERTENSIVE NUTRACEUTICALS OF VIGNA SP BEAN PROTEIN HYDROLYZED BY ALCALASE AND FLAVOURZYME
}

Tejasari Tejasari

Sih Yuwanti

Mohammad Bazar Ahmadi

Yuna Luki Afsari
Department of Agriculture Result Technology, Faculty of Agriculture Technology, University of Jember, 68121

\section{ABSTRACT}

Peptide with hydrophobic amino acids had been studied for their inhibitory activity against angiotensin-I converting enzyme (ACE-1) transformation into ACE-2 and prevention of hypertension. The active peptides may come from alcalase and flavourzyme hydrolysis of bean protein. This study aimed to measure ACE-1 inhibitory of protein hydrolysates from Vigna sp. bean (mung bean and cowpea) that grew in Indonesia, and its solubility. The bean protein (22.9 $23.6 \%$ ) was extracted using isoelectric precipitation at $\mathrm{pH}$ 4-4.6. The extracts were hydrolyzed at $\mathrm{pH} 8$ for alcalase and $\mathrm{pH} 7$ for flavourzyme, followed with inactivation at $80-85{ }^{\circ} \mathrm{C}$. ACE-1 inhibitory activity was calculated based on the amount of hippuric acid (HA) formed by the hydrolysis of Hippuryl-His-Leu (HHL), in spectrophotometry detection method (228 nm). Ultrachromatography evaluation showed that the protein hydrolysates of mungbean contained higher hydrophobic amino acids (382 mg/g protein) compared to those of cowpea (329 mg/g protein). Protein hydrolysates of both beans from alcalase hydrolysis have higher ACE-1 inhibitory activity rather than those from flavourzyme. Protein hydrolysate from Vigna spp bean protein hydrolysis by alcalase, contained small molecular weight peptides (3.9-4.63 kDa) and high ACE-1 inhibition ability (80-93\%), and therefore suggested as antihypertensive nutraceuticals. Highest solubility of protein hydrolysates resulted from alcalase hydrolysis of both beans were observed at $\mathrm{pH} 8$, while those resulted from flavorzyme hydrolysis were at $\mathrm{pH} 7$, respectively.

Keywords: ACE-1 inhibitory ability, alcalase, anti-hypertensive, flavourzyme, vigna sp

\begin{abstract}
ABSTRAK
Peptida dengan asam amino hidrofobik telah diidentifikasi berkemampuan menghambat aktivitas angiotensin-I converting enzyme (ACE-I) menjadi ACE-2 dan mencegah hipertensi. Senyawa peptide tersebut dapat berasal dari hidrolisis protein kacang-kacangan oleh alkalase dan flavorzim. Studi ini bertujuan menilai aktivitas penghambatan ACE-1 oleh hidrolisat protein dari kacang-kacangan Vigna sp (kacang hijau dan kacang tunggak) yang tumbuh di Indonesia, dan juga kelarutannya. Protein kacang (22,9 -23,6\%) diekstrak menggunakan metoda presipitasi sesuai titik isoelektrik pada $\mathrm{pH} 4-4,6$. Ekstrak dihasilkan dari hidrolisis alkalase pada $\mathrm{pH} 8$ dan flavourzyme pada $\mathrm{pH} 7$, diikuti inaktivasi pada suhu $80-85{ }^{\circ} \mathrm{C}$. Aktivitas penghambatan ACE-1 diukur berdasarkan jumlah asam hipurat (HA) yang terbentuk dari hidrolisis Hippuryl-His-Leu (HHL), dan pembacaan spektroskopi $(228 \mathrm{~nm})$. Evaluasi ultra kromatografi menunjukkan bahwa asam amino hidrofobik dalam protein hidrolisat dari kacang hijau $(382 \mathrm{mg} / \mathrm{g}$ protein) lebih tinggi dibandingkan yang berasal dari kacang tunggak $(329 \mathrm{mg} / \mathrm{g}$ protein). Aktivitas penghambatan ACE-1 lebih tinggi pada protein hidrolisat kacang Vigna sp yang dihidrolisis oleh alkalase daripada flavorzim. Protein hidrolisat kacang genus Vigna spp yang dihidrolisis oleh alkalase menghasilkan peptide molekul kecil (3,9-4,63 $\mathrm{kDa})$ dan aktivitas penghambatan ACE-1 tinggi (80-93\%), dan dengan demikian direkomendasikan sebagai nutrasetikal untuk antihipertensif. Kelaruratan terbaik hidrolisat protein kedua kacang dari hidrolisis alkalase adalah pada $\mathrm{pH} 8$ sedangkan dari hidrolisis flavorzim pada $\mathrm{pH} 7$.
\end{abstract}

Kata kunci: Aktivitas penghambatan ACE-I, alkalase, antihipertensif, flavorzim, vigna sp

\section{Article Information}

Article Type: Research Article Journal Type: Open Access Volume: 2 Issue 1

Manuscript ID v2n1381-1

Received Date 02 July 2020

Accepted Date 30 August 2020

Published Date

31 August 2020

DOI: 10.33555/jffn.v2i1.40

Corresponding author: Tejasari

Jember, Indonesia, 68121

Email: tejasari.unej@gmail.com

Citation:

Tejasari., Yuwanti, S., Ahmadi, M.B., Afsari, Y.L. 2020. The anti hypertensive nutraceuticals of Vigna sp bean protein hydrolized by alcalase and flavourzyme. J. Functional Food \& Nutraceutical, 2(1), pp.63-73

Copyright: $\odot 2020$ Swiss Germa University. This is an open-access article distributed under the terms of the Creative Commons Attribution 4.0 Internationa License, which permits unrestricted use, distribution and reproduction in any medium, provided the original author and source are credited. 


\section{INTRODUCTION}

Mung beans (Vigna radiata (L) R. Wilzeck) and cowpea (V. unguiculata (L) Walph) are protein rich vegetables with more than $20 \%$ protein content. The hydrolyzed protein of the bean grown in Afrika (Adeyemi., et al, 2012), including Nigeria (Aremu et al., 2017), and also those in China (Li et al., 2005) and Mexico (Seguro-Campos et al., 2011) were found to have inhibitory activity against angiotensin-1 converting enzyme (ACE-1) that play roles in hypertension prevention. The bean protein hydrolysate was able to inhibit the ACE-I action in becoming ACE-2, that stimulated aldosterone secretion and consequently, increased blood pressure. Such beans were also grown in Indonesia, and though not yet studied before, protein hydrolysates coming from Indonesian beans may also be a potential source of natural functional ingredients or nutraceuticals with $\mathrm{ACE}$ 1 inhibitor or antihypertensive activities.

The angiotensin-1 converting enzyme (ACE-1) inhibitory ability arises from the action of protein hydrolysates that containing a mixture of shortchain peptides (2-15 amino acid residues) with hydrophobic amino acids at their end sites, such as Arg-Lys, Val-Ala-Pro, Phe-Val-Ala-Pro, and TryPhe-Trp-Leu. Previous studies shown that the peptide composition in bean protein hydrolysates also consist of hydrophobic amino acids at the end side of its chain, that are leusine (Leu), phenylalanine (Phe), valine (Val) and isoleucine (Ileu). Previous studies have shown that the alcalase and flavourzyme,exogenous proteases, hydrolyzed the bean protein yielding the small peptides fragment with low molecular weight with high ACE-I inhibitory ability (Forghani et al., 2012; Hernandez-Ledesma dan Hsieh, 2013; Iwaniak et al., 2014). Various studies have shown that bean protein hydrolysates antihypertensive activity were correlated to their performance in inhibiting ACE-1 activity (Arihara et al., 2000; Daskaya-Dikem et al., 2017; Nakamura et al., 1995; Torruco-Uco et al., 2009).

Cowpea contains high protein (23-32\%) (Diouf, 2011) that consist hydrophobic amino acids, namely Ala, Gly, Leu, Val, Ileu, Phe, Pro, Cys, and Met; making this bean potential yielding ACE-1 inhibitor peptides (Segura-Campos et al., 2013). Mungbean contain high protein (23.7\%) (Brishti et al., 2017) and high amount of hydrophobic amino acids ( $\mathrm{Li}$ et al, 2005) as well. Objectives of the study was to evaluate the ACE-1 inhibitory ability of alcalase and flavourzyme hydrolyzed protein from two kinds of Vigna genus bean that are mung bean ( $V$. radiata $(\mathrm{L}) \mathrm{R}$. Wilzeck) and cowpea ( $V$. unguiculata (L) Walph; and therefore their potencies as antihypertensive nutraceuticals.

\section{MATERIALS AND METHOD}

\section{Materials and instruments}

The main ingredients used in the study were mung beans (Vigna radiata (L) R. Wilzeck) and cowpea (V. unguiculata (L) Walph) obtained from Tanjung Market, Jember, East Java. The enzymes used were alcalase $2.4 \mathrm{~L} \quad(2.4 \quad \mathrm{U} / \mathrm{g}) \quad\left(\begin{array}{llll}\text { Sigma } & \mathrm{P} & 4860\end{array}\right)$; flavourzyme 500L (500 U/g) (P6110 Sigma), ACEI (angiotensin-I converting enzyme) from rabbit lungs (2.0 units/mg protein) (A6778 Sigma). The chemicals used were HHL (Hippuryl-L-Histidyl-LLeucine) (H1635 Sigma), n-hexane (Merck), $\mathrm{NaOH}$ (Merck); $1 \mathrm{M} \mathrm{HCl}$ (Mediss); $\mathrm{K}_{2} \mathrm{SO}_{4} ; \mathrm{CuSO}_{4}$ $\mathrm{H}_{2} \mathrm{SO}_{4}$; MM-MB (MBC) Mediss); boric acid; trichloroacetic acid (TCA) (Merck); bovine serum albumin (BSA) (Sigma); Lowry A (FolinCiocalteau (Merck) (phosphotungstatphosphomolybdat acid solution) with aquades 1 : 1); Lowry $\mathrm{B}\left(\mathrm{Na}_{2} \mathrm{CO}_{3} 2 \%\right.$ in $1 \mathrm{~N} \mathrm{NaOH} ; 1 \%$ $\mathrm{CuSO}_{4} .5 \mathrm{H}_{2} \mathrm{O}$; sodium potassium tartaric (2\%); sodium borate buffer $\mathrm{pH} 8.3$; buffer solution $\mathrm{pH} 7$ (Merck), and aquades.

Specific instruments used were a freeze dryer (CHRIST Alpha 1-2 LD plus); shaking waterbath (StuartSBS40); centrifuge (Tomy MRX-150 and Hitachi CR21GIII); pH meter (Horiba F-51); LAF (Laminar Air Flow)(Nuaire); spectrophotometer (Hitachi type U-2900 UV-Vis); kjeldahl flask (BUTCHI); destilator (BUTCHI K-355)

\section{METHODS}

\section{Mung bean and cowpea protein extraction}

The bean were cleaned from contaminants, then grinded and sieved with an 80 mesh size. The flour was then defatted according to the method of 
Viernes et al. (2012), using n-hexane with a ratio of flour to solvent of 1:10 (w/v) for 1 hour in a cold room $\left(4{ }^{\circ} \mathrm{C}\right)$ with constant stirring. The solvent was removed by decantation, while the remaining solvent in flour precipitate was evaporated at room temperature. The dried flour was then stored in a 4 ${ }^{\circ} \mathrm{C}$ storage room until being used for further processing.

Protein extraction was performed by the isoelectric precipitation method, following the method of Lie et al. (2005) for mung bean, and the methods of Salcedo-Chavez et al. (2002) for cowpea. The material in the form of flour was suspended by adding distilled water at a ratio of 1:10 (w/v) for mung bean 1:6 (w/v) for cowpea. The highest solubility $\mathrm{pH}$ was then adjusted to $\mathrm{pH} 9$ for mung bean and $\mathrm{pH} 11$ for cowpea by adding 1 dan $2 \mathrm{M}$ $\mathrm{NaOH}$. Constant stirring was applied during $\mathrm{pH}$ adjustment using a magnetic stirrer until the $\mathrm{pH}$ was stable, and then left for $1-2$ hour with constant stirring at room temperature. Furthermore, centrifugation process was conducted to separate the dissolved protein from the material. On the mung bean flour this was carried out for 10 minutes at $5500 \mathrm{rpm}$ at $20^{\circ} \mathrm{C}$, while for the cowpea flour it was conducted for 20 minutes at 10, 000 $\mathrm{rpm}$ and at $4{ }^{\circ} \mathrm{C}$. The supernatant was separated from the precipitate for subsequent precipitation by an isoelectric $\mathrm{pH}$ setting of 4.5 and 4.6 for the bean using $1 \mathrm{~N} \mathrm{HCl}$., respectively. Constant stirring was applied during $\mathrm{pH}$ adjustment using a magnetic stirrer until the $\mathrm{pH}$ was stable, and then left for 30 minutes to allow the protein to be completely deposited. The suspension was then centrifuged again with the same time, speed and temperature as before to separate the protein and the remaining dissolved materials. The precipitate centrifugation results were separated from the supernatant, followed by a process of washing using distilled water by means of centrifugation, as previously. The protein precipitate were separated from the supernatant and dried using a freeze dryer.

\section{Enzymatic hydrolysis of the bean protein}

The enzymatic hydrolysis process was conducted using alcalase and flavourzyme enzymes, based on the procedure followed by $\mathrm{Li}$ et al. (2005) for the mung bean protein material and that of (Segura-
Campos et al., 2013) for cowpea protein material. The protein extract was suspended in distilled water at a ratio of $4 / 100(\mathrm{w} / \mathrm{v})$, accompanied by stirring using a stirrer. The ratio of the enzyme/substrate concentration of the mung bean protein extract was $20 \mu \mathrm{L} / \mathrm{g}$ protein (alcalase 0.3 AU/g; flavourzyme $50 \mathrm{LAP} \mathrm{U} / \mathrm{g}$ ). Suspension of the mung bean and cowpea protein extract was performed by adjusting to $\mathrm{pH} 8$ for alcalase and $\mathrm{pH}$ 7 for flavourzyme, respectively, by adding $1 \mathrm{~N}$ $\mathrm{NaOH}$ with constant stirring. Furthermore, the suspension was subjected to enzymatic processes at $55{ }^{\circ} \mathrm{C}$ for 120 minutes to mung bean protein extract, and at $50{ }^{\circ} \mathrm{C}$ for 90 minutes to cowpea extract protein. The hydrolysis process was performed by a shaking water bath. The hydrolysis was terminated by enzyme inactivation using heating for 10 minutes at $85{ }^{\circ} \mathrm{C}$, followed by a centrifugation process to separate the supernatant from the precipitate. Centrifugation was carried out at $4{ }^{\circ} \mathrm{C}$ at a speed of $10,000 \mathrm{rpm}$ for 20 minutes for the mung bean and cowpea protein extract material. The resulting supernatant was a protein hydrolysate containing a mixture of peptides and amino acids. The results were then dried using a freeze dryer and stored at $-20{ }^{\circ} \mathrm{C}$ until being used for further processing.

\section{Analysis of the bean protein content (AOAC, 2001)}

One gram of each mung bean and cowpea was placed into a Kjeldahl flask, followed by the addition of $7 \mathrm{~g}$ of $\mathrm{K}_{2} \mathrm{SO}_{4}, 0.8 \mathrm{~g}$ of $\mathrm{CuSO}_{4}$ and $12 \mathrm{ml}$ of concentrated $\mathrm{H}_{2} \mathrm{SO}_{4}$. The mixture was then warmed in a laminar hood for \pm 6 hours, followed by cooling for 10-20 minutes. After it had cooled, distilled water was added to make a total volume of $80 \mathrm{ml}$. A $50 \mathrm{ml} 50 \% \mathrm{NaOH}(\mathrm{w} / \mathrm{v})$ was then added, which was then distillated until $150 \mathrm{ml}$ of distillate was obtained. The resulting distillate was put into an Erlenmeyer flask with $30 \mathrm{ml}$ of $1 \% \mathrm{H}_{2} \mathrm{BO}_{3}$ (w/v) which had been dropped by 2 drops MM-MB indicator. The obtained distillate was titrated with a standard solution of $0.1 \mathrm{M} \mathrm{HCl}$ to light purple. The same treatment was performed using distilled water as a blank. The percentage of total protein content can be obtained with the following calculation: $\%$ $\mathrm{N}=((\mathrm{ml}$ sample $\mathrm{HCl}-\mathrm{ml} \mathrm{HCl}$ blank $) \times \mathrm{M} \mathrm{HCl} \times$ 
14.01) / (sample weight $\mathrm{x} 1000) \times 100 \% \%$ total protein $=\% \mathrm{~N}$ x conversion factor $(6.25)$.

\section{Composition amino acid analysis (Genetech, 2017)}

The composition of amino acids in the bean protein hydrolysate was determined using Waters Acquity UPLC $\mathrm{H}$ Class and $\mathrm{H}$ Class Bio Amino Acid Analysis System Guide year 2012. Sample was prepared using the following procedure: A $100 \mathrm{mg}$ of each mung bean and cowpea protein hydrolysate was added by $5 \mathrm{ml} \mathrm{HCl} 6 \mathrm{~N}$, homogenized, then the mixture was hydrolyzed at $110^{\circ} \mathrm{C}$ for 22 hours. Furthermore, the cool hydrolyzed mixture was diluted by adding aquabidest up to $50 \mathrm{~mL}$, and then was filtered out with a $0.45 \mu \mathrm{m}$ filter. A $500 \mu \mathrm{l}$ of the filtrate was added with $40 \mu \mathrm{m}$ AABA and 460 $\mu \mathrm{l}$ aquabidest. A $10 \mu \mathrm{l}$ of sample solution was added $70 \mu \mathrm{l}$ AccQ-flour Borate, and vortexed. Then, the homogenous solution was added with 20 $\mu \mathrm{l}$ reagent flour $\mathrm{A}$, homogenized, hushed up for one second, and incubated for 10 second at $55^{\circ} \mathrm{C}$. Standard solution was prepared using the following procedure: $40 \mu \mathrm{l}$ amino acids mix standard was added with $40 \mu \mathrm{l}$ AABA internal standard and $920 \mu \mathrm{l}$ aquabidest, and homogenized subsequently. A $10 \mu \mathrm{l}$ of the standard solution was added with $70 \mu \mathrm{l}$ AccQ-fluor Borate and vortexed. Then, the homogenous solution was added with 20 $\mu 1$ reagent flour $\mathrm{A}$, homogenized, hushed up for one second, and incubated for 10 second at $55^{\circ} \mathrm{C}$. The volume of one $\mu \mathrm{l}$ of sample solution and standard solution was injected to UPLC using ACCQ-Tag Ultra C18 column at $0.7 \mathrm{~mL}$ per minute and $49{ }^{\circ} \mathrm{C}$, and detector PDA $260 \mathrm{~nm}$. The amount of amino acids content can be obtained with the following calculation: Amino acid content $(\mathrm{mg} / \mathrm{kg})=($ area standard $/ \mathrm{AABA}$ standard $\mathrm{x} \mathrm{ml}$ Final Volume $x$ fpx $x$ C standard) / Area sample/AABA x gr sample.

\section{Degree of hydrolysis (Silvester et al., 2013)}

A $500 \mu \mathrm{l}$ of the bean protein was added with $500 \mu \mathrm{l}$ of $20 \%$ TCA and then homogenized and incubated at $4{ }^{\circ} \mathrm{C}$ for 30 minutes. The mixture was centrifuged at $6500 \mathrm{rpm}$ for 20 minutes and the supernatant analyzed for dissolved protein content based on the Lowry method (Purwanto, 2014).
Bovin Serum Albumin (BSA) was used as a protein standard. The percentage degree of hydrolysis was calculated using following calculation: $\mathrm{DH}(\%)=$ (10\% dissolved protein TCA $(\mathrm{mg})) /$ (total protein content (mg)) x 100\%

\section{Protein solubility analysis (Muhamyankaka et al., 2013)}

The bean protein hydrolysate was dissolved in distilled water $(1 \% \mathrm{w} / \mathrm{v})$ and the $\mathrm{pH}$ was adjusted (to $3,5,7,8,9,10$ and 11 ) by adding $1 \mathrm{~N} \mathrm{HCl}$ and $1 \mathrm{~N} \mathrm{NaOH}$. Constant stirring was then carried out using a magnetic stirrer for 30 minutes at room temperature $\left(25^{\circ} \mathrm{C}\right)$. Subsequently, the suspension was centrifuged for 15 minutes at $5000 \mathrm{rpm}$. The total protein in the hydrolyzate was analyzed by dissolving the hydrolyzate in $0.2 \mathrm{M} \mathrm{NaOH}(1 \%$ $\mathrm{w} / \mathrm{v})$. The content of the dissolved protein in the supernatant and suspension as a whole was measured using the Lowry method (Purwanto, 2014). The percentage of protein hydrolyzate solubility was calculated using the following formula: $\%$ Protein solubility $=($ Soluble protein sample) / (Total soluble protein) x $100 \%$

\section{Analysis of angiotensin-i converting enzyme (ACE-1) inhibitory ability (Li et al., 2005)}

Evaluation of ACE-I inhibitory ability was conducted using the principle of the formation of Hippuric Acid (HA) from the reaction of HippurylHis-Leu (HHL) with water $\left(\mathrm{H}_{2} \mathrm{O}\right)$. A sample of bean protein hydrolysate of $40 \mu \mathrm{l}(10 \mathrm{mg} / \mathrm{ml})$ was added with $100 \mu \mathrm{l}$ of $5 \mathrm{mM}$ HHL in $0.1 \mathrm{M}$ borate buffer $\mathrm{pH} 8.3$ containing $300 \mathrm{mM} \mathrm{NaCl}$, and the mixture incubated at $37^{\circ} \mathrm{C}$ for 5 minutes. A $10 \mu \mathrm{l}$ ACE-I was then added at a concentration of 100 $\mathrm{mU} / \mathrm{ml}$ and incubated for 60 minutes at $37{ }^{\circ} \mathrm{C}$. The reaction was stopped by adding $150 \mu \mathrm{l}$ of $\mathrm{HCl} 1 \mathrm{~N}$ and vortexed until homogeneous. Furthermore, 1.5 ml of ethyl acetate was added to dissolve the HA released from the HHL by ACE. The solution was then centrifuged for 10 minutes at $4000 \mathrm{rpm}$, and 1 $\mathrm{ml}$ of supernatant containing HA taken to evaporate the ethyl acetate. The HAobtained was further diluted by adding $3 \mathrm{ml}$ of distilled water and then vortexed. The solution formed was evaluated in the spectrophotometer for its absorbance at a wavelength of $228 \mathrm{~nm}$. ACE 
inhibitory activity (\%) was calculated by the following formula:

$$
\begin{array}{lcr}
\text { ACE } & \text { inhibitory activity } \\
=((B-A)) /((B-C)) \times 100 \% &
\end{array}
$$

Where: $\mathrm{A}=$ absorbance value with the addition of ACE and sample, $\mathrm{B}=$ value of control absorbance (buffer replacing sample), $\mathrm{C}=$ blank absorbance value ( $\mathrm{HCl}$ added before $\mathrm{ACE})$

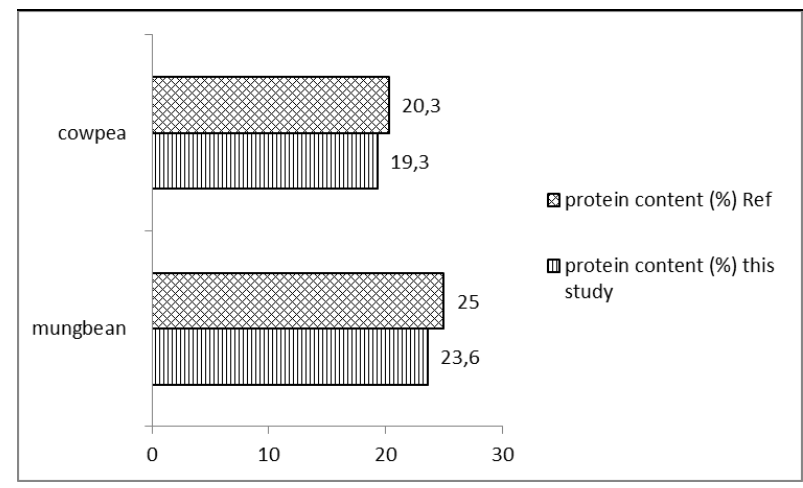

Figure 1. Comparison of protein content in mung bean and cowpea in this study and various references (Butt and Batool, 2010; Mune et al, 2013)

The levels of mung bean protein in this study were almost the same as those of Butt and Batool (2010) (23.9 percent protein content), but lower than those shown by Mubarak (2005) (25.1 percent protein content), respectively. The similarity of mung bean protein level between this study and that of Butt and Batool (2010), might be correlated to the fact that the mung bean used in the two studies were grown in Indonesia. On the other hand, Mubarak (2005) obtained higher protein content values using mung beans grown in Saudi Arabia. Carerra et al. (2011) statement, in agreement to the fact, stated that different types of climate and soil where a bean grows and develops lead to nutritional variation, including the protein content.

Total protein content of cowpea evaluated in this study (19.3\%, Figure 1) had different values compared to $20.3 \%$ protein content observed in Mune et al. (2013) and Khalid and Elharradallou (2013). The cowpea used in this research was grown in Indonesia while the other studies mentioned before used beans grown in Sudan, and Kamerun. Differences of cultivars may also play role in the nutritional variation (Habibullah et al.,2007).

\section{Protein and hydrophobic amino acids content of mung bean and cowpea protein extract}

The mung bean and cowpea protein content from the protein extract were 72.0 and $64.2 \%$, respectively. These results were higher (for mung bean) but lower (for cowpea) in comparison to previous studies. Comparison data of the protein content in bean protein extract and in protein hydrolysates from the results of this study and or those of others can be seen in Figure 2. Mungbean protein extract contained higher protein content value than cowpea in the results of this research. The result is in conjunction with previous studies.

The protein content of the mung bean protein extract from the results of this research were lower than previous studies (Bristhi et al.,2017; Sibt-eAbbas et al., 2016; Butt and Batool, 2010). On the other hand, cowpea protein extract in this research consisted of protein value of $(62.5 \%)$ higher than previous studies (Mwasaru, et al.,1999; Adeyemi et al.,2012; Frota, et al., 2017). While differences in climate and soil type where the bean grown might play a role in the variation, differences in protein extraction methods might also have an influence.

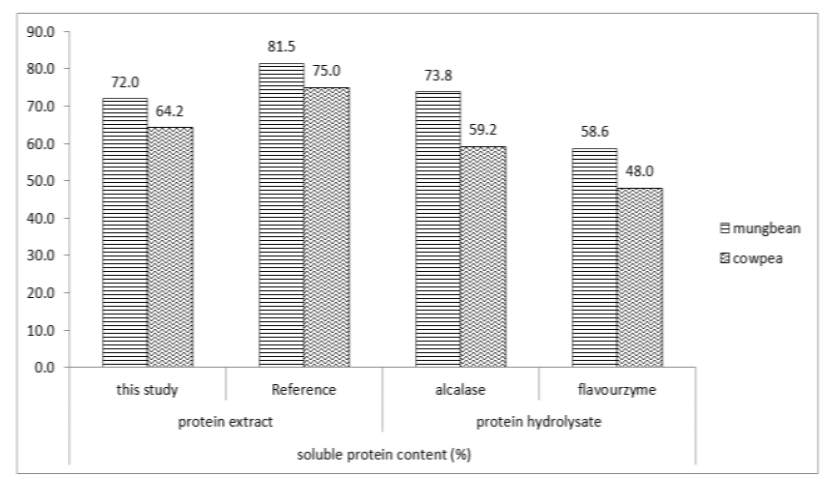

Figure 2. Comparison of protein content in extract protein and its protein hydrolysates of mung bean and cowpea in this study and other references

(Bristhi et al., 2017; Khalid and Elharadallau, 2013) 
The mung bean and cowpea hydrolysate protein in this study had lower protein values than hydrolysate protein found by other researchers. A comparison of the protein content in bean protein hydrolysate can be seen in Figure 2. The data in the figure showed that alcalase hydrolyzed protein both in the mung bean and cowpea had a higher protein content than those in flavourzyme hydrolyzed protein The protein hydrolyzate content of mung bean protein and cowpea hydrolyzed alcalase were higher than those of flavourzyme because alcalase enzymes hydrolyzes peptides with broad specificity, releasing hydrophobic peptide bonds such as Phe, Tyr, Trp, Leu, Ile, Val and Met (Doucet et al., 2003), which have the potential to be ACE-I inhibitors (Li et al., 2005). In addition, the enzyme flavourzyme contains protease complex endoproteinase and exopeptidase, with greater exopeptidase activity. This enzyme is only specific in breaking the peptide bonds in the leucine amino acids located in the amine group (Fonsseca et al., 2016).

With regard to amino acid, its amount and character or composition in a peptide determine the quality and physiological role of protein. Many essential amino acids are hydrophobic, but only little of those are hydrophilic. Peptides are produced from the alcalase hydrolyzed process of extract protein that is composed of hydrophobic amino acids at the end site of its chain, which is known to have ACE-1 inhibiting ability. Mung bean extract protein hydrolyzed alcalase produced five peptides with following order Lys-Asp-TryArg-Leu,Phe or Val-Thr-Pro-Ala-Leu-Arg and Lys-Leu-Pro-Ala-Gly-Thr (Li et al., 2006). Data in Table 1 showed that the amount of two amino acids groups in this research were lower compared to other research findings. Furthermore, the hydrophobic amino acids content in mung bean and cowpea extract protein was lower than that of hydrophilic amino acids, similar to the reference findings. This study analysis data showed that mung bean extract protein contained higher hydrophobic amino acids than that of in cowpea (Table 1), Potentially, alcalase hydrolyzed mung bean protein produced high amount peptides composed of hydrophobic amino acids that having high ACE-1 inhibitory ability.

Table 1. Comparison of amino acids in mungbean and cowpea protein extract in this research and other studies

\begin{tabular}{|c|c|c|c|c|c|}
\hline \multirow{3}{*}{ Amino acids group } & \multirow{3}{*}{ Kind of amino acids } & \multicolumn{4}{|c|}{ Content (mg/g protein) } \\
\hline & & \multicolumn{2}{|c|}{${ }^{1}$ This Study } & \multirow{2}{*}{ 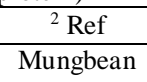 } & \multirow{2}{*}{$\begin{array}{c}{ }^{3} \text { Ref } \\
\text { Cowpea }\end{array}$} \\
\hline & & Mungbean & Cowpea & & \\
\hline \multirow[t]{12}{*}{ Hydrophobic } & *Isoleucine (Ile) & $38.48 \pm 0.18$ & $35.64 \pm 0.13$ & 64.5 & 44.9 \\
\hline & *Leusine (Leu) & $73.45 \pm 0.34$ & $66.95 \pm 0.27$ & 69.1 & 94.5 \\
\hline & *Methionine(Met) & $10.87 \pm 0.03$ & $10.47 \pm 0.04$ & 130.0 & 2.2 \\
\hline & *Cystein (Cys) & $0.88 \pm 0.01$ & $1.10 \pm 0.01$ & 43.0 & 12.4 \\
\hline & *Phenilalanin (Phe) & $67.62 \pm 0.33$ & $46.77 \pm 0.17$ & 53.1 & 55.8 \\
\hline & *Trypthophan (Tryp) & $5.02 \pm 0.12$ & $6.08 \pm 0.01$ & 2.7 & 2.7 \\
\hline & *Tyrosine (Tyr) & $30.05 \pm 0.13$ & $23.51 \pm 0.08$ & 26.6 & 21.3 \\
\hline & *Valin (Val) & $43.98 \pm 0.06$ & $39.22 \pm 0.13$ & 32.4 & 54.6 \\
\hline & Serin (Ser) & $45.31 \pm 0.18$ & $39.76 \pm 0.13$ & 53.2 & 66.5 \\
\hline & Prolin (Pro) & $34.28 \pm 0.07$ & $30.77 \pm 0.01$ & 43.0 & 49.1 \\
\hline & Alanin (Ala) & $32.33 \pm 0.13$ & $28.73 \pm 0.10$ & 29.7 & 66.3 \\
\hline & & 382.24 & 328.97 & 547.3 & 470.3 \\
\hline \multirow[t]{8}{*}{ Hydrophylic } & Arginin (Arg) & $57.19 \pm 0.22$ & $47.24 \pm 0.14$ & 46.0 & 36.5 \\
\hline & Aspartat (Asp) & $92.67 \pm 0.29$ & $75.07 \pm 0.29$ & 98.0 & 130.3 \\
\hline & Glutamat (Glu) & $159.20 \pm 0.85$ & $136.38 \pm 0.46$ & 203.0 & 155.6 \\
\hline & Glysin (Gly) & $30.73 \pm 0.08$ & $26.63 \pm 0.06$ & 28.7 & 66.3 \\
\hline & Histidine (His) & $27.02 \pm 0.21$ & $23.47 \pm 0.07$ & 37.5 & 34.5 \\
\hline & *Lysine (Lys) & $73.14 \pm 0.33$ & $71.33 \pm 0.25$ & 140.2 & 65.0 \\
\hline & *Threonin (Thr) & $26.52 \pm 0.13$ & $27.25 \pm 0.05$ & 48.8 & 42.5 \\
\hline & & 466.45 & 407.36 & 602.2 & 530.7 \\
\hline
\end{tabular}

* essential amino acids $\quad{ }^{\mathbf{1}}$ this study result ${ }^{\mathbf{2}}$ Ref: Mune et al., (2013) ${ }^{\mathbf{3}}$ Ref: Bristhi et al., (2017) 


\section{Protein hydrolysis degree and the solubility of mung bean and cowpea protein hydrolysates}

The degree of protein hydrolysis can be expressed as an indicator of the success of the hydrolysis process. The higher the percentage, the better the hydrolysis. Figure 3 shows that the values of the degree of hydrolysis in mung bean and cowpea protein hydrolyzed by alcalase were higher than with the use of flavourzyme $(43>23 \%$ and $49>34 \%)$. The difference was due to the enzyme specificity of the substrate. Mung bean protein is rich in protein sources of hydrophobic amino acids such as Phe, Tyr, Trp, Leu, Ile, Val and Met. Different types of enzymes used in the hydrolysis process will produce different degrees of hydrolysis. Alcalase is an alkaline protease that is able to produce bioactive peptides with ACE-I inhibitory activity.

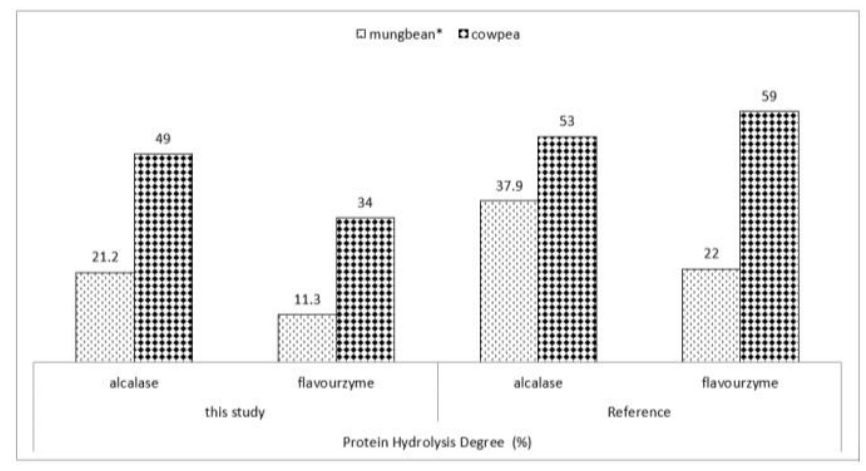

Figure 3. The degree hydrolysis values of mung bean and cowpea protein hydrolysed by alcalase and flavourzyme

Alcalase enzymes hydrolyses peptides with broad specificity, releasing bonds of hydrophobic peptides such as Phe, Tyr, Trp, Leu, Ile, Val and Met (Doucet et al., 2003), which have the potential to be ACE-inhibitors ( $\mathrm{Li}$ et al., 2005). On the other hand, the enzyme flavourzyme contains protease complex endoproteinase and exopeptidase, with greater exopeptidase activity. This enzyme is only specific in breaking the peptide bonds in the leucine amino acids located in the amine group (Fonsseca et al., 2016). It can therefore be concluded that mung bean and cowpea were good substrates for alcalase enzymes to produce antihypertensive peptides. Solubilities of mung bean and cowpea protein hydrolyzed by alcalase were highest at $\mathrm{pH} 8$. While the solubilities of those hydrolyzed by flavourzyme were highest at pH 7 (Figure 4).

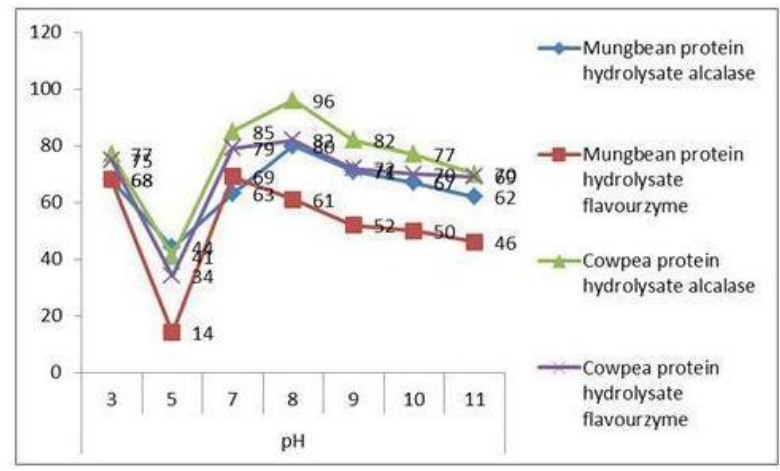

Figure 4. The solubility of mungbean and cowpea protein hydrolyzed by alcalase and flavourzyme

The SDS-PAGE electrophoresis of mungbean and cowpea protein hydrolysates showed that the fractions or peptides molecular weight ranged in between $22.6-46.3 \mathrm{kDa}$. However, after alcalase hydrolyzed, the mung bean and cowpea protein hydrolysates fractions or peptides were having smaller molecular weight ranged in between 3.0$8.7 \mathrm{kDa}$ (Figure 5).

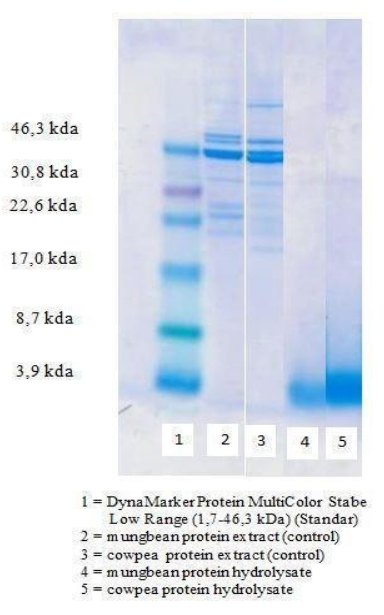

Figure 5. Fractination of mung bean and cowpea protein hydrolysed by alcalase on the molecular weight basis 


\section{ACE-I inhibiting ability}

Angiotensin-I converting enzyme (ACE-I), a peptidyl peptide hydrolase enzyme plays a role in increasing blood pressure in the body. ACE-I inhibitory activity determines the potential of an ingredient utilization as an antihypertensive agent. The ACE-I enzyme used in this study was isolated from rabbit lungs and commercialized for research purposes may be used in testing the antihypertensive potential of an inhibitor in vitro. ACE-I inhibitory activity analysis was performed by reacting the protein hydrolyzate with HippurylHis-Leu (HHL) and involved an inhibitor; in this case the inhibitor used was in the form of protein hydrolyzate in order to obtain a percentage value of the ACE-I inhibition of an inhibitor. Comparison of the ACE-I inhibitory activity of mung bean protein and cowpea protein in this research and other studies can be seen in Table 2 .

Table 2. Comparison of the ACE-I inhibitory activity of mung beanand cowpea protein in this research and other studies

\begin{tabular}{|c|c|c|c|}
\hline \multirow{2}{*}{ Bean hydrolysates } & \multicolumn{2}{|c|}{ ACE-1 inhibitory (\%) } & \multirow{2}{*}{ Source } \\
\hline & Alcalase & Flavorzyme & \\
\hline Mungbean (Vigna radiata L. R. Wilczek) (VIMA-1) & 91 & 72 & this study \\
\hline Mungbean (Vigna radiata) & 79 & - & Li et al. (2005) \\
\hline Cowpea (Vigna unguiculata L. Walph) & 80 & 77 & this study \\
\hline
\end{tabular}

From the data in Table 2, the inhibition values of ACE-I mung bean protein hydrolyzed by alcalase and flavourzyme were 91 and 72 percent, respectively. While, the ACE-I inhibition value of cowpea protein hydrolyzed by alcalase and flavourzyme were 80 and 77 percent, respectively. The ACE-I inhibition of mung bean and that of cowpea protein hydrolyzed by alcalase and flavourzyme in this study were higher than previous studies. The evaluation in this study confirmed that the protein of mung bean and cowpea grown in Indonesia, and hydrolyzed by both enzymes had considerably high ACE-I inhibitory ability, since the values were above 70 percent.

The high ACE-I inhibitory activity of mung bean and cowpea hydrolyzate protein may be due to the presence of peptide content with short peptide chains (2-5 amino acid) and C-terminal proline or hydroxyproline residues, peptide chain that have stronger inhibitory effect, since theybind to ACE-I more strongly. Proline, lysine and arginine are the preferred C-terminal substrates for ACE-I, contributing greatly to the inhibition of ACE-I (Erdmann et al., 2008). These enzymatic hydrolyzed peptides have a strong affinity with the active side of the ACE-I enzyme and can interfere with its catalytic activity in hydrolyzing the hippuril-histidyl-leucine (HHL) substrate in in vitro tests, giving high percentage inhibition (Ryan et al., 2011).

Mung bean and cowpea protein hydrolyzed by alcalase expressed higher inhibitory values than those hydrolyzed by flavourzyme. This might due to the fact that enzymatic hydrolysis of proteins using alcalases tends to produce peptides with $\mathrm{C}$ terminal amino acids in aromatic and aliphatic side chains, such as Ile, Leu, Val, Met, Phe, Try and Trp (Doucet et al., 2003). The alcalase enzyme is a group of endopeptidase enzymes that can cut peptide bonds in the middle of the chain of hydrophobic amino acids. In addition, the enzyme flavourzyme also has the ability of both enzyme endopeptidase and exopeptidase, which can cut peptide bonds in the middle or at the end of the chain of combined amino acids, especially in leucine amino acids (Leu) (Fonsseca et al., 2016).

\section{CONCLUSION}

The alcalase and flavourzyme hydrolysed protein of mungbean and cowpea grown in Indonesia, were 
able to inhibit the activity of angiotensin-I converting enzyme (ACE-I) with inhibitory values greater than 70 percent. The amount of hydrophobic amino acids in mungbean protein extract that hydrolysed by alcalase, was higher than that of in cowpea protein extract. This might play a role in the higher ability of ACE-1 inhibitory by mung bean protein hydrolysate $(91 \%)$ than that of cowpea protein extract $(80 \%)$. The solubilities of alcalase hydrolyzed mung bean and cowpea protein were highest at $\mathrm{pH} 8$. While the solubilities of those hydrolyzed by flavourzyme were highest at pH 7. The ACE-I inhibitory activity of these two bean protein hydrolysates were considerably high, and may be potential for further exploration as antihypertensive nutraceuticals.

\section{ACKNOWLEDGMENTS}

Our gratitude goes to the Indonesian Ministry of Research, Technology, and High Education, thru Institutional Research Grant Year 2019 which provided funding for conducting the research, as well as to those who have assisted in the research

\section{REFERENCES}

Adeyemi S., Lewu F B., Adebola P O., Bradley G., Olcoh A I. 2012. Protein content variation in cowpea genotype (Vigna unguiculata L. Walph)grown in eastern Cape Province of South Africa as affected by mineralised goat manure. African Journal of Agricultural Research 7(35):4943-4947.

AOAC. 2001. AOAC Offical Method 2001. 11: Protein (Crude) in Animal Feeds, Forage (Plant Tissue), Grain, and Oilseeds. AOAC International.

Arihara, K., Nakashima, Y., Mukai, T., Ishikawa, S. and Itoh, M. 2000. Peptide inhibitors for angiotensin-I converting enzyme from enzymatic hydrolysates of porcine skeletal muscle proteins. Meat Science, 57: 319-324.

Bristhi F H., Zarei M., Muhammad S K S., IsmailFifty M R., Shukri R., Saari N. 2017.

Evaluation of functional propertyes of mungbean protein isolate for development of textured vegertable protein. International Food Research Journal. 24(4):1595-1605.

Butt M S and Batool, R. 2010. Nutritional and functional properties of some promising legumes protein isolates. Journal of Nutrition. 9(4): 373-379.

Balti, R., Bougatef, A., Ali, N.E., Zekri, D., Barkia, A.andNasri, M. 2010. Influence of degree hydrolysis on functional properties and angiotensin i-converting enzyme-inhibitory activity of protein hydrolysates from cuttlefish (Sepia officinalis) by-products. Journal Science of Food and Agriculture. 90: 20062014.

Carerra, C.S., Reynoso,C.M., Funes,G.J., Martinez, M.J., Dardanelli,J. andResnik, S.L. 2011. Amino acid composition of soybean seeds as affected by climatic variables. Pesq. Agropec. Bras. 46: 1576-1587.

Daskaya-Dikmen, C.A., Yucetepe, F. Karbancioglu-Guler, H. Daskaya and B.Ozoelik.,2017. Angioten-I-converting enzyme (ACE)-inhibitory peptide from plants. Nutrients.9: 314-316.

Doucet, D., Otter, D.E., Gauthier,S.F. and Foegeding.E.A. 2003. Enzyme-induced gelation of extensively hydrolyzed whey proteins by alcalase: peptide identification and determination of enzyme specificity. J. Agric. Food Chem. 51: 6300-6308.

Erdmann, K B., Cheung W Y., and Schroder H. 2008. The possible role of food derived bioactive peptides in reducing the risk of cardiovascular disesase. Journal of Nutritional Biochemistry. 19(10):643-653.

Fonseca, R.A.S., Silva,C.M., Fernandes,G.R.and Prentice, C. 2016. Enzymatic hydrolysis of cobia (Rachycentron canadum) meat and wastes using different microbial enzymes. International Food Research Journal. 23(1): 152-160.

Forghani B., Ebrahimpour A., Bakar J., Hamid A A., Hassan Z., Sari N. 2012. Enzyme 
hydrolysate from Sticopus horrensas a new source for Angiotensine converting enzyme inhibitory peptides. Research Article : Evidence Based Complementary and Alternative Medicine : 1-9.

Frota, K M G., Lopes L A R., Silva I C V., Areas J A G.2017. Nutritional quality of the protein of (Vigna unguiculata $\mathrm{L}$. Walph) and its protein isolate. Revista Ciencia Agronomica 48(5): 792-798.

Genetech,S I. 2017. Waters Acquity UPLC H Class and H Class Bio Amino Acid Analysis System Guide Year 2012. USA.

Habibullah, A,M., and Shah, S. 2007. Proximate and mineral composition of mung bean. Journal of Agriculture. 23(2): 463-466.

Hernandez-Ledesma, B. and Hsieh, C. 2013. Bioactive food peptide in health and disease. Croatia: Intech.

Khalid, I. I., Elharadallou, S. B. 2013. Functional Properties of Cowpea (Vigna ungiculata L.Walp), and Lupin (Lupinus Termis) Flour and Protein Isolates. J Nutr Food Sci 3: 234.

Li, G.H., Liu,G. W., Le, H. and Shi., Y.H. 2005. Mung-bean protein hydrolysates obtained with alcalase exhibit angiotensin i-converting enzyme inhibitory activity. Journal of Food Science Technology Int. 11(4): 281-287.

Mubarak A.E. 2005. Nutritional composition anti nutritional factorsof mungbean seeds as affected by some home traditional processes. Food Chemistry. 89:489-495.

Muhamyankaka, V., Shoemaker,C.F., Nalwoga,M. andZhang,X.M. 2013. Physicochemical properties of hydrolysates from enzymatic hydrolysis of pumpkin (Cucurbita moschata) protein meals. International Food Research Journal. 20(5): 2227-2240.

Mune, M. A. M., Samuel, R. M., Israël, L. M. 2013. Chemical Composition and Nutritional Evaluation of a Cowpea Protein Concentrate.
Glo. Adv. Res. J. Food. Sci. Technol. 2(3) pp. 035-043

Mwasaru, M A., Muhammad K., Bakar J., and Man Y B C. 1999. Effect of isolation technique and condition on the extrractabulity, psychochemical and functional properties of pigeon pea (Cajanus cajan) and cowpea protein isolate. Food Chemistry 67(4): 435443.

Nakamura, Y., Yamamoto, N., Sakai, K., Okubo, A., Yamazaki, S. and Takano, T. 1995. Purification and characterization of angiotensin I-converting enzyme inhibitors from sour milk. Journal of Dairy Sci. 78: 777-783.

Nio, O.K. 2012. Food material analysis. Jakarta: Faculty of Medicine, University of Indonesia.

Purwanto, M.G.M. 2014. Comparison of soluble protein content analysis with various UVvisible spectroscopic methods. Journal of Science and Technology. 2(7): 64-71.

Ryan, J.T., Ross, R.P., Bolton, D., Fitzgerald, G.F. and Stanton, C. 2011. Bioactive Peptides from Musc. le Source: Meat and Fish. Nutrients. 3: 765-791.

Salcedo-Chavez B., Osuna-Castro J A., Guevaralara F., Dominguez-Dominguez J and ParedesLopez O. 2002. Optimization of isoelectric presipitation method to obtain protein isolate from amaranth (Amaranthus cruentus) seeds. Journal Agric.Food Chem. 50(22):6515-6520.

Segura-Campos, M.R., Carlos, P.E, Luis,A. C. and David, A. B. 2013. ACE-I inhibitory peptide fractions from enzymatic hydrolysates of velvet bean (Mucuna pruriens). Agricultural Sciences. 4: 767-773.

Shevkani, K., N.Singh, A.Kaur, dan Rana, J.C. 2015. Structural and functional characterization of kidney bean and field pea protein isolates: A comparative study. Food Hydrocolloids. 43: 679-689.

Sibt-e-Abbas M., Butt M S., Sultan M T., Sharif M K., Ahmad A H., and Batool R. 2016. 
Nutritional and functional properties of protein isolates extracted from deffattef peanut fluor. Journal International Food Research. 22(4): 1533-1537.

Silvestre, M.P.C., Morais,H.A., Silva, V.D.and Silva, M.R. 2013. Degree of hydrolysis and peptide profile of whey proteins using pancreatin. Journal Brazilian Society and Food Nutrition. 38(3): 278-290.

Torucco-Uco, J., Chel-Guerrero, L., MartinezAlaya, A., dan Davila-Oritz, G. 2009. Angiotensin-I converting enzyme inhibitory and antioxidant activities of protein hydrolisates from phaseolus lunatus and phaseolus vulgaris seeds. Food Science Technology Research. 42: 1597-1604.

Viernes L B G., Graccia R N., Torio M A O., and Angelia M R N. 2012. Antihypertensive peptides from vicilli, the major storage protein of mung bean (Vigna radiata L. R Wilzeck) Journal of Biological Science. 12(3): 393-399. 